EGU21-11949

https://doi.org/10.5194/egusphere-egu21-11949

EGU General Assembly 2021

(c) Author(s) 2021. This work is distributed under

the Creative Commons Attribution 4.0 License.

\title{
Evolution of strain patterns in deforming upper plates in subduction zones: the case study of Cretaceous extension in the Iranian plateau
}

Tiphaine Larvet, Laetitia Le Pourhiet, and Philippe Agard

Sorbonne Universite, ISTeP, France

Existing plate tectonic models rely on two essential features: (1) rigid tectonic plates and (2) very narrow plate boundaries where all deformation is localized. On the world geological map, plate boundaries are materialized by lines. Subduction plate boundaries, however, affect domains several hundred kilometers wide. In the upper plate of subduction zones, this deformation can result in the formation of orogenic-like compressive structures or extensional back-arc basins. In both cases, the respective contributions of slab movements, far-field stresses (i.e., boundary conditions) and tectonic inheritance in localizing strain in the upper plate are not yet well understood.

Located in the upper plate of the Late Triassic to Oligocene Neotethys subduction, the Iranian plateau records a long-lived convergence history, with numerous episodes of intraplate deformation. We herein focus on the Cretaceous back-arc opening (e.g., formation of the NainBaft marginal basin), whose possible triggers include a change in internal slab dynamics and/or regional-scale convergence dynamics (e.g., kinematics of the Neotethyan subduction, ridge subduction, opening of peripheral basins such as the Caspian Sea).

The Iranian plateau is part of a composite continental lithosphere made of blocks detached from Gondwana during the Paleozoic. It preserves evidence for structures inherited from the Precambrian Panafrican orogeny, as well as thinning and shortening during the opening and closure of the Paleotethys (during the Devonian and Late Triassic, respectively). Important lateral contrasts are observed after the Neotethys Permian rifting: the southwestern part (SanandajSirjan Zone) was thinned and filled with volcanic products, whereas the northeastern part (KopehDag and Yadz block) was thickened during the Late Triassic Cimmerian event. From NW to SE, deformation was also likely partitioned across large-scale strike-slip faults such as the Doruneh fault. These imprints make it difficult to assess the nature and extent of lateral heterogeneities in the crust, and in particular the variation of Moho depths prior to the Cretaceous extension.

In order to determine which parameters controlled the deformation of the Iranian upper plate, ultimately leading to localized back-arc extension along the Nain-Baft basin (i.e., SE of the Doruneh fault), we designed a parametric numerical study using the thermo-mechanical code pTatin2D, in which metamorphic reactions were implemented to model the subduction process realistically. 
Model results are evaluated based on the evolution of strain in the upper plate, in particular the characteristic size $(\sim 500 \mathrm{~km})$ and duration of back-arc deformation ( $30 \mathrm{Ma}$ of extension prior to closure of this domain). The importance of structural inheritance is assessed by imposing either (1) a prexisiting crustal scale fault, (2) a partially thickened (3) or thinned crust. Those different tests allow to propose tentative geodynamic scenarios for the deformation of the upper plate Iranian plateau during the Cretaceous. 